\section{Bell Pepper Seedling Growth and Yield following Pretransplant Nutritional Conditioning}

\author{
Robert J. Dufault ${ }^{1}$ \\ Coastal Research and Education Center, Department of Horticulture, Clemson \\ University, 2865 Savannah Highway, Charleston, SC 29414
}

Jonathan R. Schultheis ${ }^{2}$

North Carolina State University, Department of Horticulture, 264 Kilgore Hall, Raleigh, NC 27696-7609

Additional index words. Capsicum annuum, Solanaceae, transplant, hardening, nitrogen, phosphorus, stand establishment

Abstract. To reduce transplant shock of bell peppers (Capsicum annuum L.), we tested the effectiveness of pretransplant nutritional conditioning (PNC) as a promoter of earliness and yield. In Expt. 1, 'Gatorbelle' bell pepper seedlings were fertilized with $\mathbf{N}$ from $\mathrm{Ca}\left(\mathrm{NO}_{3}\right)_{2}$ at 25, 75, or $225 \mathrm{mg} \cdot l i t r^{-1}$ and $\mathrm{P}$ from $\mathrm{Ca}\left(\mathrm{H}_{2} \mathrm{PO}_{4}\right)_{2}$ at 5, 15, or $45 \mathrm{mg} \cdot l i t e r^{-1}$. Nitrogen interacted with $P$, affecting shoot fresh and dry weight, leaf area, root dry weight, seedling height, and leaf count. In Expt. 2, transplants conditioned with $\mathrm{N}$ from 50, 100, and $200 \mathrm{mg}$.liter ${ }^{-1}$ and $P$ at 15, 30, and $60 \mathrm{mg}^{-}$liter $^{-1}$ were field-planted in Charleston, S.C., and Clinton, N.C. Nitrogen- and P-PNC did not greatly affect recovery from transplant shock. Although N- and P-PNC affected seedling growth in the greenhouse, earliness, total yield, and quality were similar in field studies among all PNC treatments at both locations. PNC with $50 \mathrm{mg} \mathrm{N}$ and $15 \mathrm{mg} P /$ liter can be used with this variety and not have any long-term detrimental effects on yield and quality.

Commercial bell pepper fields in North and South Carolina are established using transplants. Transplant growers may harden bell pepper seedlings by withdrawing nutrients to slow growth until shipment. Hardening is thought to prepare seedlings to withstand the rigors and stresses of mechanical or hand transplanting. Nutrient-hardened transplants, however, may be slower to recover even when sufficient $\mathrm{N}$ is applied after transplanting (Aloni et al., 1991). Slow recovery from transplant shock and nutrient hardening may delay early yields and delay marketing.

Bell peppers characteristically experience a long period of transplant shock after field planting. Knavel (1977) stated that N deficiency may delay bell pepper harvest and excessive $\mathrm{N}$ may limit total yield. A variety of vegetable crops have responded to certain transplant nutritional regimes with positive results (Dufault, 1986; Masson et al., 1991; Melton and Dufault, 1991b; Tremblay et al., 1987; Weston and Zandstra, 1989). The nutritional needs for production of quality bell pepper transplants remain undefined. It is unknown if transplant nutrition has any long-

Received for publication 24 Jan. 1994. Accepted for publication 24 Apr. 1994. Technical contribution no. 3561 of the South Carolina Agricultural Expt. Station, Clemson Univ. The cost of publishing this paper was defrayed in part by the payment of page charges. Under postal regulations, this paper therefore must be hereby marked advertisement solely to indicate this fact.

${ }^{1}$ Associate Professor.

${ }^{2}$ Assistant Professor. term effect on reducing transplant shock or enhancing earliness, yield, or quality of bell peppers. However, pretransplant nutritional conditioning (PNC) may predispose greenhouse-grown seedlings to recover more rapidly from transplant shock and enhance earlier yields (Dufault, 1994).

Our objectives were to determine 1) the relative importance of $\mathrm{N}$ and $\mathrm{P}$ fertilization regimes on bell pepper seedling growth (Expt. 1) and 2) the long-term effects in the field of short-term N- and P-PNC on field growth, early and total yields, and quality in two diverse locations in North and South Carolina (Expt. 2).

\section{Materials and Methods}

Influence of $N$ and $P$ on seedling growth (Expt. 1.). 'Gatorbelle' bell pepper seeds were planted in plastic nine-cell containers $(3.5 \mathrm{~cm}$ wide $\times 5.4 \mathrm{~cm}$ deep, $66-\mathrm{cm}^{3}$ volume) filled with a commercial peat-lite medium (RediEarth mix; W.R. Grace, Allentown, Pa.) on 9 Jan. 1991. Soil tests showed that the medium contained (in mg.liter ${ }^{-1}$ ) $1 \mathrm{~N}-3 \mathrm{P}-108 \mathrm{~K}$ with a $6.8 \mathrm{pH}$. Nutrient solutions consisted of factorial combinations of $\mathrm{N}$ from $\mathrm{Ca}\left(\mathrm{NO}_{3}\right)_{2}$ and $\mathrm{P}$ from $\mathrm{Ca}\left(\mathrm{H}_{2} \mathrm{PO}_{4}\right)$ at low, medium, and high concentrations $\left(25,75\right.$, and $225 \mathrm{mg} \cdot \mathrm{liter}^{-1}$ and 5,15 , and $45 \mathrm{mg} \cdot \mathrm{liter}^{-1}$, respectively). Because total $\mathrm{Ca}$ varied by $\mathrm{N}$ treatment and the highest $\mathrm{N}$ rate contained $347 \mathrm{mg} \mathrm{Ca} /$ liter, all treatment solutions were adjusted to $347 \mathrm{mg} \mathrm{Ca} /$ liter with $\mathrm{CaCO}_{3}$ to avoid confounding. Each treatment solution also included the following (in mg.liter ${ }^{-1}$ ): $\mathrm{K}_{2} \mathrm{SO}_{4}, 100$; $\mathrm{MgSO}_{4}, 70$; and mi- cronutrients, 313 with STEM (Soluble Trace Element Mix) (Peter's Fertilizer Products; W.R. Grace $)(\mathrm{S}=15 \%, \mathrm{~B}=1.45 \%, \mathrm{Cu}=3.2 \%$, $\mathrm{Fe}=7.5 \%, \mathrm{Mn}=8.2 \%, \mathrm{Mo}=0.046 \%, \mathrm{Zn}=$ $4.5 \%$ ). The $\mathrm{pH}$ of the nutrient solutions was adjusted to 6.5 using $\mathrm{H}_{2} \mathrm{SO}_{4}$ or $\mathrm{NaOH}$, as needed. The flats were placed in a greenhouse in Charleston, S.C., with an average day maximum and night minimum of 32 and $21 \mathrm{C}$, respectively. Each plot, consisting of nine plants, was replicated four times, and was arranged in a randomized complete-block design.

Nutrients were first applied at the first fully expanded true-leaf stage on 22 Jan. and then on 24, 26, 29, and 31 Jan. and 2, 5, 7, 9, 12, 14 , and $16 \mathrm{Feb}$. 1991. The cell packs were floated in $38 \times 25 \times 9-\mathrm{cm}$, plastic storage boxes (Max Klein Co., Baraboo, Wis.) for $1 \mathrm{~h}$. Then, the cell packs were allowed to drain for $1 \mathrm{~h}$ and were returned to their respective bench locations. Seedlings were overhead-irrigated with tap water $\left(\mathrm{pH} 7.1,0 \mathrm{NO}_{3}-0.3 \mathrm{PO}_{4} \mathrm{P}-1.3 \mathrm{~K}\right)$ as needed between nutrient applications. The study ended 38 days after seeding, when seedlings were at the appropriate transplanting size and the following growth variables were measured: shoot fresh and dry (dry for $24 \mathrm{~h}$ at $65 \mathrm{C}$ ) weights, seedling height (from medium surface to tip of apical meristem), leaf area including petiole [with a leaf area meter (model 3100; LI-COR, Lincoln, Neb.], expanded trueleaf number (leaves with clearly visible petioles), and washed root dry (dry for $24 \mathrm{~h}$ at $65 \mathrm{C}$ ) weights. Growth data were analyzed using an analysis of variance (ANOVA). The relative importance of $\mathrm{N}$ - and P-PNC and their interactions were determined by partitioning the total sum of squares for treatments into main and interaction effects and expressing these individual contributions to variation as a percentage of the sum of squares for the model (composed of only those sources of variation in the ANOVA). If main or interaction effects were significant, regression analysis was used to indicate significant trends.

Short-term $N$ - and P-PNC during transplant production and subsequent responses in the field. (Expt. 2.). Todd inverted-pyramid cells $\left(3.8 \mathrm{~cm}\right.$ wide $\times 6.4 \mathrm{~cm}$ deep, $30.5-\mathrm{cm}^{3}$ volume) (Speedling, Sun City, Fla.) were filled with the same medium as in Expt. 1, and the medium was sprayed with STEM at 0.32 ml.liter ${ }^{-1}$ on 18 Mar. 1991. 'Gatorbelle' bell pepper seeds were planted on 19 Mar. in Charleston, S.C. The seeded flats were placed in a dark germination room at $32 \mathrm{C}$ for 1 week and then in a greenhouse with an average day maximum and night minimum of 33 and $16 \mathrm{C}$, respectively.

Nutrient solutions, containing the same N and $\mathrm{P}$ sources as in Expt. 1, consisted of low, medium, and high factorial combinations of $\mathrm{N}$ and $P$ at 50, 100, and 200 and 15, 30, and 60 mg.liter ${ }^{-1}$, respectively. Based on the outcome of Expt. 1, N and P rates were adjusted in Expt. 2. Potassium, $\mathrm{Mg}, \mathrm{Ca}$, and $\mathrm{pH}$ levels were adjusted as in Expt. 1. Each treatment plot included 20 plants for field planting and was replicated 4 times in a randomized completeblock design. 
The first PNC treatment began at the first, fully expanded, true-leaf stage on $1 \mathrm{Apr}$. and then on $3,5,8,10,12,15,17,19$, and $22 \mathrm{Apr}$. Greenhouse cultural practices were the same as in Expt. 1. The greenhouse growth period was terminated 22 Apr., 34 days after seeding.

Charleston. The soil type was a Yauhannah loamy fine sand, an Aquic Hapludults. The field was broadcast-fertilized with (in $\mathrm{kg} \cdot \mathrm{ha}^{-1}$ ) $60 \mathrm{~N}-27 \mathrm{P}-52 \mathrm{~K}$ before planting. Ten nonhardened plants per treatment plot were handplanted in the field on $22 \mathrm{Apr} .1991$ at Clemson Univ.'s Coastal Research and Education Center, Charleston. Plants were spaced $0.3 \mathrm{~m}$ apart within rows on beds separated by $0.9 \mathrm{~m}$. Each treatment was replicated four times in a randomized complete-block design. All plants were sidedressed with (in kg.ha ${ }^{-1}$ ) 60N-27P$52 \mathrm{~K}$ on 22 Apr., 13 May, and 13 June. Standard commercial pesticides were used to control insects and disease (Cook, 1991).

Transplant shock was evaluated 12 days after transplanting by determining the percentage of all leaves exhibiting leaf necrosis. All percentage data was transformed before analysis (Little, 1985). Days to first flower and first pod set were evaluated for the same five plants within each plot three times weekly. Firm-walled pods were harvested on 19 June, and 1 and 18 July. All mature and immature pods were harvested from the plants at the last harvest. All pods were graded into U.S. fancy and no. 1 and 2 quality categories (U.S. Dept. of Agriculture, 1963). All data were analyzed as in Expt. 1.

Clinton. The soil type was a Norfolk loamy sand, a Typic Paleudults. Pepper transplants, grown in Charleston were transported by car to the Horticultural Research Crops Station in Clinton on 22 Apr. and transplanted 23 Apr. Ten nonhardened plants per treatment plot were spaced $0.3 \mathrm{~m}$ apart within rows on beds separated by $0.9 \mathrm{~m}$. Each treatment was replicated four times in a randomized completeblock design. All plants were sidedressed with (in $\mathrm{kg} \cdot \mathrm{ha}^{-1}$ ) 30N-14P-26K on 6 and 20 May and 3 June. Standard commercial pesticides were used to control insects and disease (College Agriculture Life Science, 1991).

On 17 May, plant vigor was evaluated by visually judging canopy growth (width and height), color, and leafiness and rated according to the following subjective scale: $1=$ lowest, $2=$ moderately low, $3=$ fair, $4=$ moderate, and $5=$ highest vigor. Vigor data were transformed before analysis (Little, 1985). Days to first flower and first pod set were evaluated for the same three plants within each plot three times weekly. Firm-walled pods were harvested on 21, and 28 June and 5, 12, and 29 July and graded by the same standards used at the Charleston site. On the last harvest, all mature and immature pods were harvested and graded. All data were analyzed as in Expt. 1.

\section{Results and Discussion}

Influence of $N$ and $P$ on seedling growth (Expt. 1). Seedling growth was generally responsive to $\mathrm{N}$-and P-PNC. Nitrogen accounted for more variation in shoot fresh and dry

Table 1. Sources of variation in the analysis of variance (ANOVA) for the effects of N- and P-PNC on bell pepper seedling growth in the greenhouse 38 days after seeding and 12 nutrition conditioning cycles in Expt. 1.

\begin{tabular}{|c|c|c|c|c|c|c|}
\hline \multirow[b]{2}{*}{ Source of variation ${ }^{2}$} & \multicolumn{2}{|c|}{ Shoot wt (g) } & \multirow{2}{*}{$\begin{array}{l}\text { Seedling ht } \\
(\mathrm{cm})\end{array}$} & \multirow{2}{*}{$\begin{array}{l}\text { Leaf area/ } \\
\text { seedling } \\
\left(\mathrm{cm}^{2}\right)\end{array}$} & \multirow{2}{*}{$\begin{array}{l}\text { Leaves/ } \\
\text { seedling }\end{array}$} & \multirow{2}{*}{$\begin{array}{l}\text { Root } \\
\text { dry wt } \\
\text { (g) } \\
\end{array}$} \\
\hline & Fresh & Dry & & & & \\
\hline$\overline{\operatorname{Rep}}$ & $2^{*}$ & $17^{* *}$ & $2^{*}$ & 1 & 1 & $18^{* *}$ \\
\hline $\mathrm{N}$ & $36^{* *}$ & $22^{* *}$ & $17^{* *}$ & $39^{* *}$ & $23^{* *}$ & $20^{* *}$ \\
\hline $\mathrm{P}$ & $28^{* *}$ & $12^{* *}$ & $33^{* *}$ & $26^{* *}$ & $33^{* *}$ & $9^{* *}$ \\
\hline NP & $15^{*}$ & $7^{* *}$ & $12^{* *}$ & $16^{* *}$ & $13^{* *}$ & $7^{* * *}$ \\
\hline Error & 19 & 42 & 36 & 18 & 30 & 46 \\
\hline
\end{tabular}

${ }^{2}$ Expressed as a percentage of the total sum of squares for variation in the ANOVA.

*** F test significant at $P \leq 0.05$ or 0.01 , respectively.

weights, leaf area, and root dry weight than $\mathrm{P}$, but seedling height and leaf count were more affected by the main effect of $\mathrm{P}$ than $\mathrm{N}$ (Table 1). Melton and Dufault (1991a) indicated that $\mathrm{N}$ affected tomato (Lycopersicon esculentum Mill.) plant height, stem diameter, leaf count and area, total chlorophyll, shoot fresh weight, and shoot and root dry weights more than P.

Nitrogen interacted with $\mathrm{P}$ for all seedling growth variables responding differently to $\mathrm{N}$ and $\mathrm{P}$ combinations (Table 2). At low $\mathrm{N}$, increasing $\mathrm{P}$ rate from low to high did not affect shoot fresh and dry weights, leaf area, and leaf count. However, at medium or high $\mathrm{N}$ rates, these variables linearly increased with increasing $\mathrm{P}$ rate. At low $\mathrm{P}$, increasing the $\mathrm{N}$ rate from low to high had no effect on these variables. At medium or high $\mathrm{P}$, however, these variables curvilinearly increased with low or medium N, but this response leveled off with high N. Height control in transplants is an important production consideration for transplant growers. Seedling height increased linearly with $\mathrm{P}$ rates at all $\mathrm{N}$ rates. High $\mathrm{P}$ combined with medium $\mathrm{N}$ produced the tallest seedlings of all N-P combinations. Root dry weight did not respond to increasing $\mathrm{P}$ from low to high rates at either low or medium $\mathrm{N}$. Phosphorus-PNC only affected root dry weight if combined with high $\mathrm{N}$ because weight increased linearly with increasing $\mathrm{P}$ rate.

Short-term N-and P-PNC during transplant production and subsequent response in field (Expt. 2)

Transplant shock and preharvest growthCharleston. In general, the incidence of necrotic leaves and earliness of first flower were intensified more with $\mathrm{N}$ than $\mathrm{P}$. Comparison of the main effects of $\mathrm{N}$ and $\mathrm{P}$ indicated that $\mathrm{N}$ accounted for $44 \%$ and $\mathrm{P}$ for $11 \%$ of the variation in leaf necrosis (data not shown). Only $\mathrm{N}$ contributed significant portions of variation (17\%) to days to first flower, with the major portion $(47 \%)$ attributable to uncontrolled error. Neither $\mathrm{N}$ nor $\mathrm{P}$ affected days to first pod.

Leaf necrosis was highly visible and easily evaluated 12 days after transplanting. None of the PNC treatments affected the total number of leaves per seedling, but $\mathrm{N}$ and $\mathrm{P}$ interacted with leaf necrosis, varying by treatment. At low $\mathrm{N}$, increasing the $\mathrm{P}$ rate from low to medium did not affect leaf necrosis, but at high $\mathrm{P}$, necrosis rapidly increased (Table 3 ). As the Prate increased from low to high, leaf necrosis
Table 2. Interaction of $\mathrm{N}$ - and $\mathrm{P}-\mathrm{PNC}$ on bell pepper seedling growth in the greenhouse 38 days after seeding and 12 nutritional conditioning cycles in Expt. 1.

\begin{tabular}{|c|c|c|c|c|}
\hline \multirow[b]{2}{*}{$\mathrm{N}\left(\mathrm{mg} \cdot\right.$ liter $\left.^{-1}\right)$} & \multicolumn{3}{|c|}{$\mathrm{P}\left(\mathrm{mg} \cdot \mathrm{liter}^{-1}\right)$} & \multirow[b]{2}{*}{ Significance $^{z}$} \\
\hline & 5 & 15 & 45 & \\
\hline \multicolumn{5}{|c|}{ Shoot fresh $w t(\mathrm{~g})$} \\
\hline 25 & 1.9 & 2.1 & 2.0 & NS \\
\hline 75 & 2.6 & 3.0 & 3.5 & $\mathrm{~L}^{* *}$ \\
\hline 225 & 1.9 & 2.7 & 3.8 & $\mathrm{~L}^{* *}$ \\
\hline Significance $^{y}$ & NS & $\mathrm{Q}^{* *}$ & $\mathrm{Q}^{* * *}$ & \\
\hline \multicolumn{5}{|c|}{ Shoot dry wt $(g)$} \\
\hline 25 & 0.35 & 0.37 & 0.35 & NS \\
\hline 75 & 0.42 & 0.46 & 0.49 & $\mathrm{~L}^{* *}$ \\
\hline 225 & 0.36 & 0.43 & 0.50 & $\mathrm{~L}^{* *}$ \\
\hline Significance & NS & $\mathrm{Q}^{* *}$ & $\mathrm{Q}^{* *}$ & \\
\hline \multicolumn{5}{|c|}{ Seedling $\mathrm{ht}(\mathrm{cm})$} \\
\hline 25 & 9.7 & 10.3 & 10.9 & $\mathrm{~L}^{* *}$ \\
\hline 75 & 10.8 & 11.6 & 12.8 & $\mathrm{~L}^{* *}$ \\
\hline 225 & 8.9 & 10.8 & 12.3 & $\mathrm{~L}^{* *}$ \\
\hline Significance & NS & NS & $\mathrm{Q}^{* *}$ & \\
\hline \multicolumn{5}{|c|}{ Leaf area/seedling $\left(\mathrm{cm}^{2}\right)$} \\
\hline 25 & 42.2 & 46.7 & 43.1 & NS \\
\hline 75 & 59.3 & 73.6 & 84.8 & $\mathrm{~L}^{* *}$ \\
\hline 225 & 44.4 & 65.9 & 92.2 & $\mathrm{~L}^{* *}$ \\
\hline Significance & NS & $\mathrm{Q}^{* *}$ & $\mathrm{Q}^{* *}$ & \\
\hline \multicolumn{5}{|c|}{ Leaves/seedling } \\
\hline 25 & 5.7 & 6.1 & 5.9 & NS \\
\hline 75 & 6.1 & 6.5 & 7.2 & $\mathrm{~L}^{* *}$ \\
\hline 225 & 5.7 & 6.4 & 7.1 & $\mathrm{~L}^{* *}$ \\
\hline Significance & NS & $\mathrm{Q}^{* *}$ & $\mathrm{Q}^{* *}$ & \\
\hline \multicolumn{5}{|c|}{ Root dry wt $(\mathrm{g})$} \\
\hline 25 & 1.1 & 1.2 & 1.1 & NS \\
\hline 75 & 1.3 & 1.5 & 1.4 & NS \\
\hline 225 & 1.1 & 1.3 & 1.5 & $\mathrm{~L}^{* *}$ \\
\hline Significance & NS & NS & $\mathrm{Q}^{* *}$ & \\
\hline
\end{tabular}

${ }^{\mathrm{z}} \mathrm{L}=$ linear effect and $\mathrm{Q}=$ quadratic effect; indicates significance of increasing $\mathrm{P}$ rate with $\mathrm{N}$ held constant.

${ }^{\mathrm{y}}$ Indicates significance of increasing $\mathrm{N}$ rate with $\mathrm{P}$ held constant.

Ns, ${ }^{* *} \mathrm{~F}$ test nonsignificant or significant at $P \leq 0.01$, respectively.

linearly decreased at the medium $\mathrm{N}$ rate, but at high $\mathrm{N}$, increasing the $\mathrm{P}$ rate had no effect.

First flowering occurred 25 days after transplanting and 13 days after evaluating transplant shock. Only the main effect of $\mathrm{N}$ was significant and plants conditioned with medium $\mathrm{N}$ flowered by 25 days after transplanting (data not shown). Plants conditioned with low and high $\mathrm{N}$ flowered 26 and 27 days after transplanting, respectively. We consider this response minor because none of the PNC treatments affected earlier fruit set.

Preharvest growth-Clinton. The main 
Table 3. Interaction between N- and P-PNC on bell pepper leaf necrosis 12 days after transplanting at Charleston, S.C., Expt. 2.

\begin{tabular}{lcccc}
\hline \hline & \multicolumn{3}{c}{$\mathrm{P}\left(\mathrm{mg} \cdot\right.$ liter $\left.^{-1}\right)$} \\
\cline { 2 - 4 } $\mathrm{N}\left(\mathrm{mg} \cdot\right.$ liter $\left.^{-1}\right)$ & 15 & 30 & 60 & Significance \\
\hline \multicolumn{4}{c}{${\text { Necrotic leaves/plant }(\%)^{y}}$} \\
50 & 5.5 & 2.8 & 14.7 & $\mathrm{Q}^{* *}$ \\
100 & 13.9 & 13.0 & 12.5 & $\mathrm{~L}^{* *}$ \\
200 & 20.9 & 15.5 & 23.0 & $\mathrm{NS}$ \\
Significance $^{\mathrm{x}}$ & $\mathrm{L}^{* *}$ & $\mathrm{Q}^{* *}$ & $\mathrm{Q}^{* *}$ &
\end{tabular}

${ }^{ } \mathrm{L}=$ linear effect and $\mathrm{Q}=$ quadratic effect; indicates significance of increasing $\mathrm{P}$ rate with $\mathrm{N}$ held contrast

yTransformed data presented.

${ }^{x}$ Indicates significance of increasing $\mathrm{N}$ rate with $\mathrm{P}$ held constant.

${ }^{\mathrm{Ns},}{ }^{* *} \mathrm{~F}$ test nonsignificant or significant at $P \leq 0.01$ respectively.

Table 4. Interaction between N- and P-PNC on bell pepper plant vigor 24 days after transplanting and days to first flower in Clinton, N.C., Expt. 2.

\begin{tabular}{lcccc}
\hline \hline & \multicolumn{3}{c}{$\mathrm{P}\left(\mathrm{mg} \cdot\right.$ liter $\left.^{-1}\right)$} \\
\cline { 2 - 4 } $\mathrm{N}\left(\mathrm{mg}^{\prime}\right.$ liter $\left.^{-1}\right)$ & 15 & 30 & 60 & Significance $^{z}$ \\
\hline \multicolumn{4}{c}{ Plant vigor (rating) } \\
50 & 3.6 & 2.9 & 3.6 & $\mathrm{NS}$ \\
100 & 2.9 & 3.9 & 3.9 & $\mathrm{Q}^{* *}$ \\
200 & 2.4 & 3.9 & 4.1 & $\mathrm{~L}^{* *}$ \\
Significance & $\mathrm{L}^{* *}$ & $\mathrm{Q}^{* *}$ & $\mathrm{~L}^{* *}$ & \\
50 & Days to first flower & \\
100 & 33 & 34 & 34 & $\mathrm{NS}$ \\
200 & 37 & 32 & 33 & $\mathrm{Q}^{* *}$ \\
Significance & 38 & 31 & 27 & $\mathrm{~L}^{* *}$ \\
& $\mathrm{Q}^{* *}$ & $\mathrm{NS}$ & $\mathrm{L}^{* *}$ &
\end{tabular}

${ }^{\mathrm{z}} \mathrm{L}=$ linear effect and $\mathrm{Q}=$ quadratic effect; indicates significance of increasing $\mathrm{P}$ rate with $\mathrm{N}$ held contrast.

${ }^{\mathrm{y}}$ Vigor judged on canopy width and height, color, and leafiness; 1 = lowest, $2=$ moderately low, 3 = fair, $4=$ moderate, and $5=$ greatest vigor.

${ }^{x}$ Indicates significance of increasing $\mathrm{N}$ rate with $\mathrm{P}$ held constant.

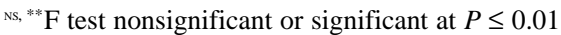
respectively.

effect of $\mathrm{P}$ and the $\mathrm{N} \times \mathrm{P}$ interaction affected plant vigor and days to first flower, but neither $\mathrm{N}$ nor $\mathrm{P}$ affected days to first pod (data not shown). The main effect of $\mathrm{P}$ and the $\mathrm{N} \times \mathrm{P}$ interaction accounted for $22 \%$ and $26 \%$, respectively, of the variation in vigor and $24 \%$ and $25 \%$, respectively, of the variation in days to first flower.

Increasing the $\mathrm{P}$ rate at the low $\mathrm{N}$ rate had no effect on plant vigor and days to first flower (Table 4). At medium $\mathrm{N}$, increasing the $\mathrm{P}$ rate to medium curvilinearly increased plant vigor and promoted earlier flowering, but with no further effect from high P. Plant vigor increased linearly, and the plants flowered earlier with increasing $P$ rate in combination with high N. Plant vigor linearly decreased with increasing $\mathrm{N}$ rate at a constant low $\mathrm{P}$ rate, but
Table 5. Effect of N- and P-PNC on bell pepper marketable yield from three harvests at Charleston, S.C., Expt. 2.

\begin{tabular}{lccc}
\hline \hline & \multicolumn{3}{c}{$\mathrm{P}\left(\mathrm{mg} \cdot\right.$ liter $\left.^{-1}\right)$} \\
\cline { 2 - 4 } $\mathrm{N}\left(\mathrm{mg} \cdot\right.$ liter $\left.^{-1}\right)$ & 15 & 30 & 60 \\
\hline \multicolumn{4}{c}{ Yield $\left(t \cdot h a^{-1}\right)^{z}$} \\
50 & 17.8 & 14.4 & 13.0 \\
100 & 16.8 & 14.3 & 18.6 \\
200 & 16.0 & 13.7 & 11.1
\end{tabular}

${ }^{\mathrm{z}}$ Main effects of $\mathrm{N}$ and $\mathrm{P}$ and their interactions and interactions between either $\mathrm{N}$ or $\mathrm{P}$ with harvest time were not significant at $P \leq 0.05$.

flowering was delayed with medium to high $N$. However, this effect reversed when increasing $\mathrm{N}$ rate was combined with high $\mathrm{P}$; vigor increased linearly, and flowering occurred 7 days earlier as $\mathrm{N}$ increased from low to high rates.

Yield and quality-Charleston and Clinton. Short-term N- and P-PNC during transplant production did not significantly affect early and total yields and quality at Charleston. Although transplant shock increased with N$\mathrm{PNC}$, the plants recovered and produced yields statistically equivalent to seedlings grown at low N- and P-PNC in both locations (Table 5). Trends in the biological yields indicated that some PNC regimes may not be suitable for transplant production. The plants conditioned with high $\mathrm{N}$ and $\mathrm{P}$ yielded $37 \%$ and $40 \%$ less marketable weight, respectively, than those conditioned with low or high $\mathrm{N}$ and $\mathrm{P}$.

In Clinton, early and total yields and quality were not affected by PNC; however, N interacted with harvest time, affecting marketable yields in the fourth and fifth harvests (Table 6). As $\mathrm{N}$ increased from low to high, yields increased linearly in the fourth harvest, but in the fifth harvest, the response was curvilinear, with lower yields with medium $\mathrm{N}$ than with the low or high $\mathrm{N}$ rates.

Vigorous 'Gatorbelle' pepper transplants, conditioned with $\mathrm{N}$ and $\mathrm{P} \geq 50$ and 15 $\mathrm{mg} \cdot$ liter $^{-1}$, respectively, responded similarly to seedlings conditioned with $\mathrm{N}$ and $\mathrm{P}$ at 100 and $60 \mathrm{mg} \cdot$ liter $^{-1}$ in both Carolina locations. Because earliness was not affected by transplant nutrition, recovery from transplant shock was similar with seedlings conditioned with these PNC regimes. PNC had no advantage with this cultivar, but it is unknown if other bell pepper cultivars would respond similarly. These results differ from those reported on 'Sunny' tomato, which produced greater total yields after conditioning with $\mathrm{N}$ at 100 vs. 50 mg.liter ${ }^{-1}$ (Melton and Dufault, 1991b). Our results suggest that low $\mathrm{N}$ and $\mathrm{P}$ seedling fertility can be used with 'Gatorbelle' pepper without any long-term detrimental or beneficial effects on yield and quality.
Table 6. Interaction between harvest time and $\mathrm{N}$ PNC on marketable yield $\left(\mathrm{t} \cdot \mathrm{ha}^{-1}\right)$ for five harvests of bell peppers at Clinton, N.C., Expt. 2.

\begin{tabular}{lrrrc}
\hline \hline Harvest & \multicolumn{3}{c}{$\mathrm{N}\left(\mathrm{mg} \cdot\right.$ liter $\left.^{-1}\right)$} & \\
\cline { 2 - 4 } no. $^{\mathrm{z}}$ & \multicolumn{1}{c}{50} & 100 & 200 & Significance $^{\mathrm{y}}$ \\
\hline 1 & 5.9 & 4.5 & 5.8 & $\mathrm{NS}$ \\
2 & 7.9 & 6.9 & 5.7 & $\mathrm{NS}$ \\
3 & 11.0 & 9.0 & 7.3 & $\mathrm{NS}$ \\
4 & 14.0 & 17.0 & 17.5 & $\mathrm{~L}^{*}$ \\
5 & 15.3 & 14.0 & 17.8 & $\mathrm{Q}^{* *}$ \\
Total & 54.1 & 51.4 & 54.1 & $\mathrm{NS}$
\end{tabular}

${ }^{\mathrm{z}} 1$ = 21 June, 2 = 28 June, 3 = 5 July, 4 = 12 July, and $5=29$ July.

${ }^{\mathrm{y}} \mathrm{L}=$ linear effect and $\mathrm{Q}=$ quadratic effect; indicates significance of increasing $\mathrm{N}$ rate within a harvest.

Ns, ${ }^{*},{ }^{* *} \mathrm{~F}$ test nonsignificant or significant at $P \leq 0.05$ or 0.01 , respectively.

\section{Literature Cited}

Aloni B., T. Pashkar, and L. Karni. 1991. Nitrogen supply influence carbohydrate partitioning of pepper seedlings and transplant development. J. Amer. Soc. Hort. 116:995-999.

College Agriculture Life Sciences. 1991. The 1991 North Carolina agricultural chemical manual. North Carolina State Univ., Raleigh.

Cook, W. 1991. 1991 Agricultural chemical handbook. Clemson Univ. Coop. Ext. Serv. Publ. EC 670 .

Dufault, R.J. 1986. Influence of nutritional conditioning on muskmelon transplant quality and early yield. J. Amer. Soc. Hort. Sci. 115:698703.

Dufault, R.J. 1994. Long-term consequences and significance of short-term pretransplant nutritional conditioning. HortTechnolology 4:4142.

Knavel, D.E. 1977. The influences of nitrogen on pepper transplant growth and yielding potential of plants grown with different levels of soil nitrogen. J. Amer. Soc. Hort. Sci. 102:533-535.

Little, T.M. 1985. Analysis of percentage and rating scale data. HortScience 20:642-644.

Masson, J., N. Tremblay, and A. Gosselin. 1991. Effects of nitrogen fertilization and HPS supplementary lighting on vegetable transplants production. I. Transplant growth. J. Amer. Soc. Hort. Sci. 116:594-598.

Melton, R.R. and R.J. Dufault. 1991a. Nitrogen, phosphorus, and potassium fertility regimes affect tomato transplant growth. HortScience 26:141-142.

Melton, R.R. and R.J. Dufault. 1991b. Tomato seedling growth, earliness, yield, and quality following pretransplant nutritional conditioning and low temperatures. J. Amer. Soc. Hort. Sci. 116:421-425.

Tremblay, N., S. Yelle, and A. Gosselin. 1987. Effects of $\mathrm{CO}_{2}$ enrichment, nitrogen and phosphorus fertilization on growth and yield of celery transplants. HortScience 22:875-876.

U.S. Department of Agriculture. 1963. United States standards for grades of sweet peppers. U.S. Dept. of Agriculture, Washington, D.C.

Weston, L.A. and B.H. Zandstra. 1989. Transplant age and $\mathrm{N}$ and $\mathrm{P}$ nutrition effects on growth and yield of tomatoes. HortScience 24:88-90. 